\title{
PENGARUH VARIABEL EKONOMI MAKRO TERHADAP PEMBIAYAAN PERBANKAN SYARIAH PERIODE 2010-2018
}

\author{
Mirza Zulfikar Hisbul Rachman \\ Mintarti Ariani \\ Eko Waluyo Suwardyono \\ Fakultas Bisnis dan Ekonomika, Universitas Surabaya, Indonesia \\ Email: mirzazulfikar97@gmail.com
}

\begin{abstract}
The purpose of the research is to examine and analyze the effect of macroeconomic variables GDP and inflation on Islamic banking financing in Indonesian. Islamic bank financing is the dependent variable, whereas GDP, reference interest rates, and inflation are the independent variable. The data used is Islamic banking financing, GDP, reference interest rates, and inflation in Indonesian from 2010-1018. This empirical study uses a quantitative approach and method of OLS (Ordinary Least Square). The results of this research indicate that the GDP variable has positive and statistically significant effect on Islamic banking financing, the variable reference interest rates (BI Rate and BI Rate 7days Repo Rate) have negative and statistically significant effect on Islamic banking financing, the inflation variable has positive and statistically significant effect on Islamic banking financing.
\end{abstract}

Keyword: Islamic Banking, Gross Domestic Product, BI Rate, Inflation

\section{PENDAHULUAN}

Perbankan Syariah saat ini telah berkembang pesat dan tumbuh tersebar di seluruh dunia, baik negara dengan mayoritas masyarakat muslim maupun non-muslim. Perbankan Syariah adalah bank yang beroperasi tanpa menggunakan prinsip bunga melainkan menggunakan prinsip syariah. Prinsip Syariah adalah aturan perjanjian berdasarkan hukum Islam antara bank dan pihak lain untuk penyimpanan dana dan/atau pembiayaan kegiatan usaha, atau kegiatan lain yang dinyatakan sesuai syariah, antara lain berdasarkan prinsip bagi hasil (mudharabah), pembiayaan berdasarkan prinsip penyertaan modal (musyarakah), prinsip jual beli barang dengan memperoleh keuntungan berdasarkan prinsip sewa murni tanpa pilihan (ijarah).

Tabel 1 menggambarkan bahwa perkembangan pembiayaan perbankan syariah sejak 2010 hingga 2018 selalu mengalami peningkatan. Namun, pertumbuhan tersebut jauh lebih baik dari pertumbuhan kredit pada bank konvensional yang hanya mencapai $13-23 \%$. Hal ini menunjukkan jika perbankan syariah memiliki peluang untuk terus berkembang dari tahun ke tahun. Beberapa faktor dapat mempengaruhi pertumbuhan dari pembiayaan perbankan syariah contohnya adalah kondisi makro ekonomi Indonesia. Ada beberapa faktor makro ekonomi yang dapat mempengaruhi pembiayaan seperti Produk Domestik Bruto (PDB), suku bunga acuan Indonesia (BI Rate dan BI Rate 7 days Repo Rate), dan inflasi. Krisis ekonomi, moneter dan stabilitas politik akan membuat perubahan pada suku bunga perbankan dan akan menjadi faktor utama terjadinya fluktuasi pada kredit dan pembiayaan perbankan. 
Pertumbuhan PDB selalu mengalami peningkatan. Terjadinya peningkatan PDB mempunyai dampak terhadap kualitas pembiayaan yang diberikan oleh suatu perbankan. Ketika PDB meningkat secara teori terjadi peningkatan transaksi ekonomi, dunia bisnis menggeliat. Pertumbuhan PDB mempunyai dampak terhadap kualitas pinjaman yang diberikan oleh perbankan (Firdaus, 2015).

Tabel 1: Kondisi Makro Ekonomi \& Pembiayaan Perbankan Syariah Periode 2010-2018

\begin{tabular}{lcccccc}
\hline Tahun & $\begin{array}{c}\text { Suku } \\
\text { Bunga } \\
\text { Acuan } \\
(\%)\end{array}$ & flasi $(\%)$ & $\begin{array}{c}\text { B (milyar } \\
\text { rupiah) }\end{array}$ & $\begin{array}{l}\text { tumbuhan } \\
\text { PDB }(\%)\end{array}$ & $\begin{array}{l}\text { Jumlah } \\
\text { Pembiayaan (Rp } \\
\text { miliar) }\end{array}$ & $\begin{array}{l}\text { Perkembangan } \\
\text { Pembiayaan }(\%)\end{array}$ \\
\hline 2010 & 5,25 & 6,96 & 6.864 .133 & 6,20 & 68.181 & 45,42 \\
2011 & 4,75 & 3,79 & 7.287 .635 & 6,20 & 102.655 & 50,56 \\
2012 & 4,5 & 4,3 & 7.727 .083 & 6,00 & 147.505 & 43,69 \\
2013 & 6.25 & 8,38 & 8.156 .497 & 5,60 & 184.122 & 24,82 \\
2014 & 6,5 & 8,36 & 8.564 .866 & 5,00 & 199.330 & 8,26 \\
2015 & 6,25 & 3,35 & 8.982 .517 & 4,90 & 212.996 & 6,86 \\
2016 & 4,75 & 3,02 & 9.434 .613 & 5,00 & 248.007 & 16,44 \\
2017 & 4,25 & 3,61 & 9.912 .703 & 5,07 & 285.695 & 15,20 \\
2018 & 6 & 3,13 & 19.425 .316 & $95,96 \%$ & 320.193 & 12,08 \\
\hline
\end{tabular}

Sumber: Bank Indonesia, BPS, Statistik Perbankan Syariah, OJK 2018

*Mulai tahun 2016, Indonesia menerapkan BI 7-Day Repo Rate untuk menggantikan BI Rate sehingga BI Rate tahun sebelumnya telah disesuaikan dengan ketetapan BI 7-Day Repo Rate.

Suku Bunga Acuan dan Inflasi mengalami pertumbuhan yang fluktuatif dan disebabkan oleh berbagai kejadian yang terjadi di suatu negara. Inflasi adalah salah sau peristiwa penting dan terjadi di hampir semua negara. Dengan meningkatnya inflasi, pemerintah akan menaikkan suku bunga acuan yang nantinya akan berdampak pada terjadinya kenaikan suku bunga kredit bank umum. Hal ini akan mempengaruhi besaran pendapatan yang akan diperoleh bank dan kemampuan nasabah dalam membayar pinjamannya. Oleh karena itu bank akan lebih selektif dalam menyalurkan pembiayaan danmemilih nasabah.

Bank syariah adalah badan usaha yang fungsinya sebagai penghimpunan dana dari masyarakat dan menyalurkan dana kepada masyarakat, yang sistem dan mekanisme kegiatan usahanya berdasarkan hukum islam sebagaimana yang diatur dalam Al-Qur'an dan Hadist. (Rachmat, 2002:11). Menurut UU No.21 Tahun 2008 tentang Perbankan Syariah pasal 1 ayat 1, mendefinisikan perbankan syariah adalah segala sesuatu yang menyangkut tentang Bank Syariah dan Unit Usaha Syariah, mencangkup kelembagaan, kegiatan usaha, serta cara dan proses dalam melaksanakan kegiatan usahanya. Pembiayaan (financing) merupakan pendanaan yang diberikan oleh suatu pihak kepada pihak lain untuk mendukung investasi yang telah direncanakan, baik dilakukan sendiri maupun oleh suatu lembaga (Syahbudi, 2018).

Secara garis besar fungsi pembiayaan dalam perekonomian, perdagangan, dan keuangan (Rivai dan Andria, 2007) adalah sebagai berikut, (1). Pembiayaan sebagai alat stabilisasi ekonomi. Pembiayaan berperan penting dalam menekan arus inflasi dan 
pembangunan ekonomi. Pembiayaan harus diarahkan ke sektor-sektor produktif dan sektorsektor prioritas yang secara langsung berpengaruh terhadap hajat hidup masyarakat. (2). Pembiayaan sebagai jembatan untuk peningkatan pendapatan nasional. Apabila rata- rata pengusaha, pemilik tanah, pemilik modal, buruh/karyawan, dan masyarakat lainya mengalami peningkatan pendapatan, maka pendapatan negara via pajak bertambah, penghasilan devisa bertambah, dan penggunaan devisa untuk urusan konsumsi berkurang sehingga secara langsung atau tidak lansung, melalui pembiayaan, pendapatan negara akan bertambah.

Banyak penelitian telah dilakukan untuk mengetahui seberapa besar pengaruh faktor makro ekonomi terhadap pembiayaan perbankan syariah. Faktor makro yang pertama yaitu PDB, hasil penelitian Nahar dan Sarker (2016) menyatakan bahwa pertumbuhan PDB Berpengaruh positif dan signifikan terhadap pembiayaan bank syariah. Semakin meningkat PDB, maka akan meningkatkan peluang masyarakat untuk berinvestasi, sehingga akan mengakibatkan peningkatan supply dan demand dalam pembiayaan bank syariah.

Faktor makro yang kedua adalah suku bunga acuan Indonesia, hasil penelitian Rivai et al. (2012) menyatakan bahwa suku bunga acuan Indonesia berpengaruh negatif signifikan terhadap pembiayaan bank syariah. Dimana semakin meningkatnya suku bunga acuan (BI Rate dan BI Rate 7 days Repo Rate) maka masyarakat lebih berhati-hati dalam melakukan pinjaman di bank. Faktor makro terakhir adalah inflasi, hasil penelitian Nahar dan Sarker (2016) menyatakan bahwa inflasi berpengaruh positif terhadap pembiayaan bank syariah. Semakin meningkat tingkat inflasi maka tingkat pembiayaan yang diperlukan juga semakin meningkat.

Pembiayaan perbankan syariah di Indonesia dari 2010 hingga 2018 selalu mengalami peningkatan yang signifikan. Pada 2010 pembiayaan tercatat sebesar Rp68.181 miliar dan terus mengalami peningkatan hingga 2018 sebesar Rp 320.193 miliar (Otoritas Jasa Keuangan RI-Statistik Perbankan Syariah, 2018). Pembiayaan yang terus meningkat disebabkan oleh beberapa faktor diantaranya semakin meningkatnya kepercayaan masyarakat Indonesia.

Hipotesis yang diuji adalah:

1) Diduga PDB berpengaruh positif terhadap pembiayaan perbankan syariah di Indonesiaperiode 2010-2018

2) Diduga Suku Bunga Acuan Indonesia (BI Rate dan BI Rate 7 days Repo Rate) berpengaruhnegatif terhadap pembiayaan perbankan syariah di Indonesia periode 20102018

3) Diduga Inflasi berpengaruh positif terhadap pembiayaan perbankan syariah di Indonesiaperiode 2010-2018

\section{METODE PENELITIAN}

Penelitian ini menggunakan data yang bersifat deskriptif kuantitatif. Data yang pada dasarnya menghasilkan hasil analisis angka-angka, diolah dengan menggunakan metode statistik dan menghasilkan hubungan antara variabel yang diteliti. Adapun data time series yang digunakan adalah data tahunan yakni tahun 2010 - 2018, yang diperoleh dari berbagai sumber yaitu: Badan Pusat Statistik Indonesia, Bank Indonesia, dan Otoritas Jasa Keuangan., dan sumber lainnya.

Penelitian ini menggunakan metode Ordinary Least Square (OLS). dengan fungsi Pembiayaan bank syariah $=\mathrm{f}(\mathrm{PDB}$, Suku Bunga Acuan Indonesia, Inflasi $)$, sehingga persamaan regresi: 
Yit $=\alpha+$ BX1t + CX2t + DX3t $+\varepsilon t$

Dengan,

$\mathrm{Y}=$ pembiayaan perbankan Syariah

$\alpha=$ konstanta agresi

$\mathrm{X} 1$ = koefisien pengaruh

PDBX2 = koefisien pengaruh BI Rate

$\mathrm{X} 3=$ koefisien pengaruh Inflasi

$\mathrm{t}=$ waktu $(2010-2018)$

$\varepsilon=$ variabel pengganggu

Data yang digunakan dalam analisis ini merupakan data sekunder deret waktu (time series) mulai periode 2010-2018. Model yang digunakan sebagai alat analisis regresi linier berganda adalah Ordinary Least Square (OLS). Pengolahan dilakukan dengan menggunakan Microsoft Excel 2010 dan Eviews 9 (Tabel 2).

Tabel 2 Hasil Ordinary Least Square (OLS)

Dependent Variable: PEMBIAYAAN

Method: Least Squares

Date: 11/03/19 Time: 20:19

Sample: 20102018

Included observations: 9

\begin{tabular}{ccccc}
\hline Variable & Coefficient & Std. Error & t-Statistic & Prob. \\
\hline C & 21.35883 & 1.717391 & 12.43679 & 0.0000 \\
PDB & 2.489688 & 0.223954 & 11.11697 & 0.0000 \\
BIRATE & -0.139117 & 0.168998 & -0.823187 & 0.0412 \\
INFLASI & 0.155254 & 0.062340 & 2.490427 & 0.0149 \\
\hline R-squared & 0.860108 & Mean dependent var & 6.19111 \\
& & & 1 \\
Adjusted R-squared & 0.850761 & S.D. dependent var & 1.75258 \\
& & & 7 \\
S.E. of regression & 1.085795 & Akaike info criterion & 3.30360 \\
Sum squared resid & 5.894752 & Schwarz criterion & 4 \\
Log likelihood & -10.86622 & Hannan-Quinn criter. & 3.39125 \\
& & & 9 \\
F-statistic & 81.32577 & Durbin-Watson stat & 1.074115 \\
Prob(F-statistic) & 0.000000 & & 4 \\
\hline
\end{tabular}

Sumber: Data Primer, 2020

Berdasarkan Tabel 2, persamaan yang didapatkan sebagai berikut:

$$
\text { Pembiayaan }=21.35883+2.48968 \mathrm{PDB}-0.139117 \mathrm{BIR} \text { ate }+0.155254 \text { Inflasi }+\varepsilon \mathrm{t}
$$

Berdasarkan hasil regresi didapatkan nilai prob ( $F$ - statistic) sebesar $0.000000<\alpha$ $(0,05)$ artinya signifikan sehingga dapat disimpulkan bahwa variabel independen (PDB, Suku Bunga Acuan, Inflasi) secara bersama-sama mempengaruhi variabel dependen yaitu Pembiayaan Bank Syariah. 
Tabel 3 Hasil Regresi Pegujian Hipotesis

\begin{tabular}{cccl}
\hline Variabel & t- statisik & Prob & Keterangan \\
\hline PDB & 11.11697 & 0,0000 & Signifikan \\
BI Rate & -0.823187 & 0,0412 & Signifikan \\
Inflasi & 2.490427 & 0,0149 & Signifikan \\
\hline
\end{tabular}

Berdasarkan uji OLS yang telah dilakukan dapat disimpulkan bahwa:

1. $\mathrm{X} 1$ (PDB)

Berdasarkan hasil uji signifikansi didapatkan probabilitas $0,0000<\alpha=5 \%$ berarti signifikan (H1 diterima). PDB mempunyai koefisien sebesar 2,489688 serta berpengaruh positifterhadap pembiayaan perbankan syariah di Indonesia.

2. X2 (Suku Bunga Acuan)

Berdasarkan hasil uji signifikansi didapatkan probabilitas $0,0412<\alpha=5 \%$ berarti signifikan (H1 diterima). Suku Bunga Acuan (BI Rate dan BI Rate 7 days Repo Rate) mempunyai koefisien sebesar -0.139117 dan berpengaruh negatif terhadap pembiayaan perbankan syariah di Indonesia.

3. X3 (Inflasi)

Berdasarkan hasil uji signifikansi didapatkan probabilitas $0,0149<\alpha=5 \%$ berarti signifikan (H1 diterima). Inflasi mempunyai koefisien sebesar 0.155254 dan berpengaruh positifterhadap pembiayaan perbankan syariah di Indonesia.

Hasil uji signifikan didapatkan data adjusted R Square sebesar 0.860108 atau 86,01\%. Data tersebut menunjukkan bahwa pengaruh PDB, BI rate, inflasi terhadap Pembiayaan perbankan syariah sebesar $86,01 \%$ dan sisanya sebesar $13,99 \%$ tidak dimasukkan dalam model penelitian.

Variabel Suku Bunga Acuan (BI Rate dan BI Rate 7 days Repo Rate) signifikan dan berpengaruh negatif terhadap pembiayaan perbankan syariah. Pada tahun 2010 hingga tahun 2018 terlihat bahwa Suku Bunga Acuan (BI Rate dan BI Rate 7 days-Repo Rate) di Indonesia mengalami fluktuasi dan tidak menentu. Hal ini berimbas pada tingkat pembiayaan perbankan syariah mengalami penurunan yang disebabkan tingkat BI Rate yang cukup tinggi dibanding tahun sebelumnya. Apabila BI Rate dan BI Rate 7 days-Repo Rate naik maka akan diimbangi dengan kenaikan suku bunga kredit perbankan.

Ketika suku bunga pembiayaan suatu perbankan naik maka masyarakat akan lebih berhati-hati dalam melakukan pinjaman di perbankan, hal ini dikarenakan cicilan yang nantinya akan mereka bayar akan semakin besar. Semakin hati-hatinya masyarakat Indonesia akan mengurangi minat dan volume masyarakat untuk mengajukan pembiayaan bank syariah. Hasil penelitian ini sesuai dengan penelitian yang dilakukan oleh Rivai et al. (2012) yang menjelaskan bahwa Suku Bunga Acuan (BI Rate) berpengaruh negatif terhadap pembiayaan bank syariah.

Variabel inflasi signifikan dan berpengaruh positif terhadap pembiayaan perbankan syariah. Kenaikan harga BBM dan harga tarif listrik sebagai contoh dapat mengakibatkan kenaikan inflasi. Dampak yang paling dirasakan oleh para pelaku usaha adalah meningkatnya beban usaha atau pengeluaran yang harus mereka keluarkan. Meningkatnya beban usaha yang dirasakan dengan pendapatan tetap akan membuat pelaku usaha kesulitan dalam memenuhi biaya produksi yang harus mereka keluarkan. Berdasarkan hal tersebut, salah satu keputusan yang diambil para pelaku usaha adalah dengan menggunakan pembiayaan yang diberikan oleh perbankan syariah. 
Hasil penelitian ini sesuai dengan penelitian yang dilakukan oleh Nahar dan Sarker (2016) yang menjelaskan bahwa inflasi berpengaruh positif terhadap pembiayaan bank syariah. Penelitian ini menjelaskan jika seiring dengan meningkatnya laju inflasi pada perekonomian, harga barang dan jasa juga akan terpengaruh meningkat.

Dengan meningkatnya harga barang dan jasa, investor juga akan lebih banyak menanamkan modalnya, sehingga akan memberikan peluang untuk nasabah mengajukan pembiayaan pada perbankan syariah. Selain itu sebagai negara yang masih berkembang, dengan tingkat inflasi yang masih cukup tinggi dan cenderung tidak stabil, maka ada peluang bagi perbankan syariah di Indonesia dalam meningkatkan pembiayaannya.

\section{KESIMPULAN}

Berdasarkan hasil dari pengolahan data dan uji hipotesis yang telah dilakukan, maka terdapat kesimpulan yaitu variabel PDB berpengaruh positif signifikan terhadap pembiayaan perbankan syariah di Indonesia, variabel Suku Bunga Acuan (BI Rate BI Rate 7 days Repo Rate) berpengaruh negatif signifikan terhadap pembiayaan perbankan syariah di Indonesia, variabel Inflasi berpengaruh positif signifikan terhadap pembiayaan perbankan syariah di Indonesia. Variabel independen (PDB, Suku Bunga Acuan, Inflasi) secara bersama-sama mempengaruhi variabel dependen yaitu pembiayaan perbankan syariah.

\section{DAFTAR PUSTAKA}

Abida, Muttaqiena. 2013. Analisa Pengaruh PDB, Inflasi, Tingkat Bunga dan Nilai Tukar terhadap Dana Pihak Ketiga Perbankan Syariah di Indonesia Tahun 2008-2012. Skripsi. Semarang. Univ. Negeri Semarang

Chairu Ummah Teja Sumarna. 2018. Analisis Pengaruh Bi Rate, Nilai Tukar, Inflasi dan Capital Adequacy Ratio (CAR) Terhadap Tingkat Margin Pembiayaan Murabahah Di Bank Umum Syariah Periode 2011-2016. Skripsi. Jakarta. Fakultas Ekonomi dan Bisnis Univ. Islam Negeri Syarif Hidayatullah.

Firdaus, Rizal Nur. 2015. Pengaruh Faktor Internal dan Eksternal yang Mempengaruhi Pembiayaan Bermasalah pada Bank Umum Syariah di Indonesia. El Dinar. Vol. 3, No 1 Januari 2015. Fakultas Ekonomi dan Bisnis Univ. Brawijaya.

Nahar, Shamsun dan Sarker, Niluthpaul. 2016. Are Macroeconomic Factors Substantially Influential for Islamic Bank Financing? Cross-Country Evidence. Vol 18. No 1. IOSR Journal of Business and Management (IOSR-JBM).

Rachmat, Usman.2002. Aspek- Aspek Hokum Perbankan Islam di Indonesia. Bandung: PT. Citra Aditiya Abadi.

Syahbudi, Muhammad. 2018. Pengaruh Variabel Makro Ekonomi terhadap Pembiayaan Pada Perbankan Syariah di Indonesia. Skripsi. Medan. Fakultas Ekonomi dan Bisnis Univiversitas Islam Negeri Sumatera Utara.

Rivai, Veithzal dan Andria, Permata. 2007. Bank and Financial Institution Management. Jakarta: PT Raja Grafindo Persada.

Rivai, Veithzal, S Basir, S Sudarto, AP Veithzal. 2012. Commercial Bank Management: Manajemen. Perbankan Dari Teori Ke Praktik. Edisi 1. Jakarta: Rajawali Pers. 